\title{
The After-War Fall in Meat Prices
}

\author{
By L. D. H. WELD \\ Swift \& Company, Chicago, Ill.
}

$\mathrm{D}^{1}$ UN'S index number of wholesale prices shows that in January, 1920, the average wholesale price of meat was only 58 per cent higher than the average price for the year 1913, whereas the average wholesale price of all commodities was 105 per cent higher. Furthermore, since July, 1919, Dun's index shows that the wholesale price of meat had fallen 22 per cent (to January, 1920), whereas the average wholesale price of all commodities had risen 6 per cent during the same interval.

These facts are of peculiar significance at a time when the nation is complaining of constantly rising prices. It is not generally realized that during the past few months meat has been positively cheap as compared with other commodities, when pre-war prices, or prices of a year ago are considered.

The year 1919 was a decidedly abnormal one in the live-stock and meat trades. Prices reached unprecedentedly high levels during the first part of the year, only to be followed by spectacular declines which meant losses to many livestock producers, and also to the packers. What are the principal reasons for the remarkable price changes that have taken place? It is necessary to review conditions before and during the war before this question can be answered.

\section{How the War Affected Meat Prices}

Before the European war began, exports of beef from the United States had practically ceased. Europe was getting her beef principally from South America, for the simple reason that cattle can be raised more cheaply in that part of the world than in the United States. Between the time that the import duty on meat had been removed in 1913 and the outbreak of the war, a little Argentine beef was actually imported into the United States. Europe was still depending on us for pork products (including fats) in considerable quantity, because the United States is the only country which has a large exportable surplus. South America and Australia do not raise hogs to any considerable extent.

During the war, the allied nations found it necessary to purchase their beef from the United States, because they could not afford to let their vessels make the long journey to and from South American ports. Foreign demand for our pork products also increased, and our exports increased tremendously. Coincident with this increase in export demand, there occurred a great increase in domestic production of cattle and hogs. The receipts of cattle in seven principal markets increased 82 per cent from 1914 to 1918 ; the receipts of hogs in eleven principal markets increased 36 per cent. This did not mean a decrease in the nation's stock of live animals, because the estimates of the Department of Agriculture revealed a continuing increase in the number of 
animals on farms, at least up to and including January, 1919.

During the war, the domestic consumption of meat increased rather than decreased, in spite of the efforts of the Food Administration to curtail consumption. The campaign for saving undoubtedly kept the domestic consumption lower than it otherwise would have been, but it was largely counterbalanced by greater purchases on the part of millions of workmen who had received extraordinary advances in wages.

The net results of these factors was that during the war the prices of meats increased in about the same ratio as the prices of other commodities. Pork products went up more than the average; beef went up a little less than the average. This was the situation, in general terms, up to the time the armistice was signed in November, 1918.

\section{The Beff-Price Situation}

To explain the events since hostilities ceased it is necessary to consider beef and pork separately. As for beef, it was only natural that the disappearance of an unnatural foreign demand would bring down prices, and everybody expected this to happen. Export shipments continued for two or three months after the armistice, but as vessels became available for the lung trip to South America and to Australia, beef exports practically ceased. The effect of this situation was felt in April, 1919, when cattle and beef prices began a considerable decline.

A bulletin issued by the United States Department of Agriculture on July 1, 1919, showed that wholesale prices of beef decreased more rapidly, relatively, than the prices of live cattle. In other words, the differential between cattle prices and beef prices narrowed perceptibly. This was due partly to the fact that the prices that packers were able to realize on hides were advancing at the same time that cattle and beef prices were falling.

\section{Cause of Advance in Hide Prices}

Many people cannot understand why such a thing should happen, and say that the advance in hide prices must have been due to artificial manipulation. Such was not the case, however, because anyone who studies the situation will easily find out that the advance in hide prices was not peculiar to the United States. It was a world phenomenon, caused by large after-war demand for hides and leather by European nations, whose supply of leather had been used up, or worn out, during the war and in carrying on war operations. Except for about three weeks in May, Swift \& Company lost money on cattle operations almost continually for about five months, including the sale not only of beef, but also of cured hides, refined oils and fats, and other cattle by-products. The same was true of the other large packers. Swift \& Company's losses were so large during that period that the beef business for the whole year, 1919 , showed a loss of about 70 cents per head of cattle.

Average prices of all grades of cattle and beef continued to decline through the rest of the year, and the Department of Agriculture's estimate for January 1, 1920, shows a decline in the number of cattle on farms. This indicates that the cattlemen. many of 
whom have lost money during the past year, are adjusting their herds to peace conditions. The war demand stimulated production to such an extent that it resulted in such a large supply that it could not be marketed at a profitable price, after the export market disappeared. Cattle production is becoming adjusted to domestic demand, and will sooner or later bear its nominal relation to other agricultural crops so far as profitableness is concerned.

\section{The Pork Price Situation}

The ending of the war did not have the same effect on hog and pork prices. It was expected that the central European nations, which had been in the habit of obtaining pork and fats from the United States before the war, would renew their purchases after the war ceased. There were extremely heavy marketings of hogs during the first two months of 1919, due partly to the guaranteed price of $17 \frac{1}{2}$ cents brought about by agreement between the Food Administration and the packers, and this kept the price from rising abruptly. After the first of March, however, European demand began to show itself, hog receipts fell off, the packers anticipated still further foreign demand, and the price became higher.

The price of hogs and pork products continued to climb until July, when live hogs were sold in Chicago for over 23 cents a pound-an abnormally high price. Then came the crash. This was due, not to the fact that Europe did not want our pork, but to the fact that Europe could not pay for it. Hog marketings became relatively light, but the packers had large supplies of pork products in process of cure. Early in August the British government appointed a commission to make purchases for England in the United States. This commission-in reality a single buyer for a large part of our exportable surplus-found that there was a considerable supply on hand in England and afloat, and announced that it would not buy much pork for two or three months. The bad financial situation in other European countries was reflected in the exchange situation, and exports suddenly fell off. The result was a precipitous decline in hog and pork prices during August, September and October.

The decline in hog and pork prices last summer and fall was perhaps the most spectacular that ever occurredfrom over 23 cents to around 14 cents. It was a serious matter. Farmers lost money heavily. The packers lost heavily because of the decline in value of pork products. Swift \& Company suffered a loss of over $\$ 10,000,000$ in sixweeks on its stocks of pork products.

\section{The Price of Pork Loins}

One interesting feature of the decline in hog and pork prices was that the price of porl loins (from which are obtained pork chops and pork roasts) continued at its high level until November. This fact has been spread broadcast by the Federal Trade Commission as an indication that the packers were arbitrarily holding up the price of pork loins, even though the prices of hogs had tumbled.

The truth is that, when properly understood, the course of pork-loin prices furnishes as good a proof as any one could want that prices of meats are determined by conditions of supply 
and demand, working out through competition. Pork loins are practically the only part of the hog that is sold as fresh meat, and constitute only about 12 per cent of all the meat from an animal. It has to be sold within a few days after the animal is killed (except for a small amount that is frozen) and therefore there is never any very great reserve stock. With light current supplies of hogs, and with heavy domestic demand, there was a relative shortage of this particular cut, and the price naturally remained high.

The prices of cured hog meats, which form the bulk of the total, were falling during this period, so that the average price of all pork cuts fell approximately as the price of hogs. All this time the packers were suffering the heaviest losses on their pork operations that they had ever experienced. The price of pork loins finally dropped substantially in November, when the marketing of hogs increased (as it always does at that time of the year), although a member of the Federal Trade Commission publicly announced that the drop in price was due to the publicity that he had given the matter!

\section{European Demand and Meat Prices}

The future course of hog and pork prices is, of course, problematical, because it depends largely on the European demand for our products. As already explained, this is a factor that does not have to be considered in the beef situation. Undoubtedly, Europe will begin to get straightened out somewhat, and if she gets in a position to spend money for our pork products, this will be a factor in keeping the price higher than it otherwise would be. Europe's unsatisfactory financial and industrial condition is reflected in the foreign exchange situation, which has caused loss to exporters, and which has automatically reduced exports.

\section{Retail and Wholesale Meat Prices}

In conclusion, a word should be said about retail prices. It is undoubtedly true that they have not fallen as much as wholesale prices. That is generally the case on a declining market; retail prices lag. But they have come down substantially, as shown by the latest reports of the Bureau of Labor Statistics. It is perhaps unfortunate that retail prices do not fluctuate with wholesale prices. The day-to-day changes in wholesale meat prices are not reflected in retail prices; but when there are any decided swings upward or downward, retail prices sooner or later become adjusted to wholesale prices. 